\title{
Fire-Regulating Services and Disservices With an Application to the Haifa-Carmel Region in Israel
}

\author{
Yaella Depietri* and Daniel E. Orenstein \\ Faculty of Architecture and Town Planning, Technion - Israel Institute of Technology, Haifa, Israel
}

\section{OPEN ACCESS}

Edited by:

Sonja Knapp

Technische Universität

Berlin, Germany

Reviewed by:

Kenneth Joseph Bagstad, United States Geological Survey,

United States

Simona R. Gradinaru,

University of Bucharest, Romania

${ }^{*}$ Correspondence:

Yaella Depietri

yaella.d@technion.ac.il

Specialty section:

This article was submitted to

Land Use Dynamics,

a section of the journal

Frontiers in Environmental Science

Received: 07 March 2019

Accepted: 20 June 2019

Published: 04 July 2019

Citation:

Depietri Y and Orenstein DE (2019)

Fire-Regulating Services and

Disservices With an Application to the

Haifa-Carmel Region in Israel.

Front. Environ. Sci. 7:107.

doi: 10.3389/fenvs.2019.00107
In the Mediterranean region, and in other fire-prone areas of the globe, the risk of human and economic losses due to forest fires has increased in the past decades, particularly at the urban-wildland interface. To counter this trend, economic and human resources are generally invested to combat and suppress wildfires, with much less invested to adapt through ecosystem-based management. Ecosystem services for fire regulation are rarely accounted for in the literature and are generally excluded from ecosystem service classifications. This gap causes fire-regulating services to be overlooked in socio-ecological assessments and in economic valuations, potentially further hampering the design and implementation of ecosystem-based approaches. We review the literature on fire risk reduction related to ecosystem management to define and characterize fire-regulating services and disservices. We then suggest indicators for the assessment of these services and disservices, and we propose a conceptual framework linking fire risk, ecosystem services, and ecosystem management practices. In the second part of the paper, we apply these concepts to the historical development of the social-ecological system of the Haifa-Mount Carmel region in Israel, including pre- and post-fire forest management practices. To inform the case study we investigate reports, relevant scientific articles, and policy documents, all corroborated with information from expert lectures on the topic. We conclude by suggesting that human capital should become an integral part of the description and definition of fire-regulating services and disservices, especially for highly modified urban and peri-urban environments.

Keywords: ecosystem services, wildfires, land use change (LUC), ecosystem-based disaster risk reduction (Eco-DRR), urban areas

\section{INTRODUCTION}

Forest fires have caused extensive damage in Europe and in the U.S. in recent years. In July 2018, Greece experienced its worst fire since 2007, which caused the death of 126 people in the Attica region surrounding its capital, Athens (CRED, 2019). More than 3,200 houses were also destroyed or damaged during this event. In the same summer period, forest fires affected large parts of Sweden due to unusually warm and dry conditions. In November 2018, in California, the Camp Fire burned more than 60,700 hectares, killing 85 people and destroying more than 18,800 structures (WERT, 2018). These catastrophic fires also led to smoke-related health problems and the degradation of ecosystems.

In recent decades, diverse human activities have caused the increase in risk of catastrophic forest fires. Among these, intensive forest fire suppression, starting at the beginning of the twentieth century, and land abandonment have resulted in widespread homogeneous forest cover with, on 
average, more small trees and much greater fuel loads (Caldararo, 2002; Bowman et al., 2011; Pausas and Fernández-Muñoz, 2012). These outcome are more intense fires capable of reaching the forest canopy, causing difficult-to-control crown fires (Agee and Skinner, 2005).

Climate change, causing higher winter and summer temperatures, further increases fire risk (Westerling et al., 2006). Increased impacts from wildfires have also been associated with the expansion of the wildland-urban interface (WUI) (Radeloff et al., 2005; Cohen, 2008). Although the total area burned seems to have been decreasing in the Mediterranean area between 1985 and 2011 (Turco et al., 2016), forest fires at the WUI are instead rising. Large fires tend to occur more frequently in proximity to the WUI in many European countries and in the U.S., as more people settle in these areas, increasing exposure to wildfires and leading to higher chances of fire ignition (Blanchard and Ryan, 2007; Mell et al., 2010; Modugno et al., 2016). As such, improved management of peri-urban forests is required (IPCC, 2012; Vilà-Cabrera et al., 2018).

Traditionally, in the aftermath of a fire event, resources are channeled toward responding to fire damage through repair and restoration, or to increasing resources for firefighting and preparedness. In contrast, ecosystem-based approaches for reducing fire risk, which are characterized by the sustainable management and restoration of ecosystems to reduce disaster risk, have too often been overlooked. The case is similar for flood risk. This has been traditionally tackled through hard infrastructure and engineering approaches (e.g., building dikes or levees), but these can paradoxically lead to increased risk from catastrophic events in the long term due to the false sense of security they generate (Mitchell, 2003). In contrast, ecosystem-based approaches intervene directly in the structure and functioning of ecosystems, enhancing regulating services related to risk and providing long term solutions to avoid catastrophic events.

A way to design and promote ecosystem-based approaches is through the characterization, assessment and valuation of ecosystem services. However, fire-regulating services (and disservices) are rarely mentioned in the ecosystem service literature and are omitted from most ecosystem services classifications (Sil et al., 2019). This oversight hinders the accounting of the regulating functions of ecosystems that reduce fire risk, potentially limiting the development of ecosystem-based approaches (Modugno et al., 2016). One possible reason for this gap is the confusion that arises when trying to conceptualize ecosystem characteristics contributing to fire risk. Ecosystem elements represent, in this case, both the hazard potential and the services moderating the hazard (Haines-Young and Potschin, 2018). Biomass and vegetation types both determine fire risk, but they can also determine (limiting or increasing) the intensity, timing and duration of the fire event. Another reason may be that fire-regulating services, in order to be effective, generally require human intervention or management. While other regulating services can be more easily identified as products of the functioning of unmanaged ecosystems, requiring low degrees of human input (e.g., water regulation in forest watersheds or water purification in wetlands), fire-regulating services, we suggest, require a broader definition of ecosystem services that explicitly incorporates human activities as a necessary element of their production. This is even truer as we approach urbanized systems. Here, hybrid (mixed ecological and technological) approaches are often required to supply adequate amounts of services (Depietri and McPhearson, 2017). Likewise, fireregulating disservices, which increase the risk of catastrophic fires, are also often the result of unsustainable human activities or, conversely, of land abandonment (Lyytimäki et al., 2008).

In this paper, we define and characterize fire-regulating services and disservices. In the next section of the introduction, we review how the available ecosystem services literature relates to fire risk (section Fire Regulation in the Ecosystem Services Literature). In section Methods, we describe the methodology and the Haifa-Carmel case study, which we use to apply the framework developed in section Defining and Assessing FireRegulating Services and Disservices. In section Characteristics of the Ecosystem and Management Strategies Affecting FireRegulating Services to section Characteristics of Ecosystems and Mismanagement Leading to Fire-Regulating Disservices, we characterize fire-regulating services and disservices through a review of the literature on ecosystem management for fire risk reduction. In section Assessing Fire-Regulating Services and Disservices, we present methods to assess and value fireregulating services and disservices and in section Conceptual Framework, we suggest a theoretical framework. In section An Application to the Haifa-Carmel Case Study, we analyze the case of forest fires in the Haifa-Carmel region (Israel), detailing how fire risk and the social-ecological system coevolved in the area over the past 200 years leading to different configurations of fire-regulating services and disservices. In sections Discussion and Conclusions we discuss results and provide conclusions.

\section{Fire Regulation in the Ecosystem Services Literature}

Most of the research concerning both ecosystem services and fire risk focuses on the loss of services caused by forest fires (Hurteau et al., 2014; Lee et al., 2015; Thom and Seidl, 2016; Harper et al., 2018). Forest fires, in fact, alter water quality and carbon cycling, and can lead to changes in vegetation types and structures, at least temporarily and particularly in non-fire prone ecosystems which are more susceptible to impacts (Vaz et al., 2017; Harper et al., 2018). On the other hand, ecosystem services are provided by localized or intentionally set fires, and can include increased agricultural land, hunting opportunities, fodder and pasture, pest management, charcoal, cultural services, and nutrient recycling (Schmerbeck et al., 2015). Forest fires also regulate the density and composition of young trees, create and shape terrestrial and aquatic wildlife habitats, co-determine the spatial pattern of landscapes, and influence water and sediment delivery across watersheds (Noss et al., 2006). Pausas and Keeley (2019) provide a comprehensive list of ecosystem services provided by wildfires, including carbon balance, the reduction of catastrophic fires, decreased evapotranspiration (which increases water storage important in case of droughts), and specific cultural services, 
such as ecotourism in open ecosystems, recreational hunting, and information about ancestral fire management techniques.

While the ecosystem services framework has become a popular approach for studying human-nature relationships (Lele et al., 2013), most of the available classifications do not include fire regulation amongst the list of services (see for instance de Groot et al., 2002; Millenium Ecosystem Assessment, 2005; Wallace, 2007, 2008; Costanza, 2008; Fisher and Turner, 2008; Burkhard and Maes, 2017). Even when the category "moderating extreme events" is included, the case of forest fires is generally not acknowledged. An exception is the most recent version of the Common International Classification of Ecosystem Services (CICES) (v. 5.1).

CICES v. 5.1 covers situations in which the ecological structure of ecosystems (such as a grassland corridor or a wetland area) prevents or mitigates the risk of fire spreading between forest stands (Haines-Young and Potschin, 2018). It defines fire-regulating services as those leading to "the reduction in the incidence, intensity or speed of spread of fire by virtue of the presence of plants and animals that mitigates or prevents potential damage to human use of the environment or human health and safety." The additional definition provided by CICES expresses "the capacity of ecosystems to reduce the frequency, spread or magnitudes of fires (e.g., wetland area between forests, or fire belt in woodland containing species of low combustibility)" (https://cices.eu/content/uploads/ sites/8/2018/03/Finalized-V5.1_18032018.xlsx; retrieved on 21st January 2019). According to Haines-Young and Potschin (2018), this new category was introduced to make the classification more comprehensive.

Following the definition given by CICES v. 5.1, Campagne and Roche (2018) include fire regulation in their list of ecosystem services. However, they insert them in the accounting matrix they propose in terms of fire-regulating disservices. Based on expert judgement, the authors assigned different values to land cover types according to their relative contribution to accrued fire risk. In the matrix, the values assigned to the land cover types capacities to lead to fire-regulating disservices increase across the land-use gradient from rocky-habitat (with the least firedisservice potential) to dense coniferous forest (with the highest fire-disservice potential). Recently Sil et al. (2019) elaborate further on the concept of fire-regulating services.

We suggest that, while these definitions provide much needed attention and detail for dealing with fire-regulating services and disservice, they are incomplete as they are based on the partial definition of ecosystem services. Specifically, they lack consideration of the human role in the co-production of ecosystem services. When defining ecosystem services, the research community generally refers to those benefits that are provided by "nature" or by "natural ecosystems" (Daily, 1997; Boyd and Banzhaf, 2007; Fisher et al., 2009). The most common definitions treat ecosystem services as ecological phenomena and human beings as mere beneficiaries of these functions (Depietri et al., 2016). In the "cascade model" of de Groot et al. (2010), services seem to flow effortlessly from ecosystems to beneficiaries, as free gifts of nature (Spangenberg et al., 2014). Some researchers have instead suggested that ecosystem services are in most cases socially co-produced (Palomo et al., 2016), particularly in human-dominated environments such as urban and periurban areas (Ernstson, 2013; Depietri et al., 2016; Brockerhoff et al., 2017). This means that ecosystem services are often the subjective products of the interaction between humans and their environment, and they are extensively affected by human activity and human alteration of the landscape (Foley et al., 2005). Skills, management regimes, and technology are often involved in the production of ecosystem services (Reyers et al., 2013; Díaz et al., 2015; Outeiro et al., 2017).

Palomo et al. (2016) detail how most services, and disservices, are co-produced by a mixture of natural capital (e.g., natural resources and amenities) and various other forms of capital, including built capital (e.g., buildings, infrastructures and machines), cultural capital (e.g., knowledge, beliefs systems, traditions and language), social capital (e.g., skills, abilities, health), institutional capital (e.g., relationships, laws, institutions and organizations, formal networks), political capital (e.g., access to power, connection to resources and power brokers), and financial capital (e.g., monetary wealth). This may be selfevident when considering cultural and provisioning services. Most of the work on co-production of ecosystem services has in fact looked at provisioning services (Outeiro et al., 2017). Cultural services also have strong social factors involved in their production, such as recreational infrastructure, clearing of paths, buildings for cultural activities and management of sacred sites (Orenstein et al., 2012; Reyers et al., 2013). Regulating services, in contrast, are generally treated as though they are entirely produced by the functioning of undisturbed systems, and their provision is diminished with increasing human intervention (Braat and de Groot, 2012). We suggest, that in highly modified environments, such as urban and periurban areas, referred by some authors as social-ecologicaltechnological systems (SETS) (Grimm et al., 2016; McPhearson et al., 2016; Depietri and McPhearson, 2017; Keeler et al., 2019), regulating services too are co-produced by human activities. This recognition allows us to provide a more comprehensive definition of fire-regulating services and disservices, as detailed in the following sections.

\section{METHODS}

\section{Methodology}

We review the academic literature in the domain of fire risk management and fire risk reduction, particularly that with ecological relevance. We used this literature to define fire-regulating service and disservices and to identify the characteristics of ecosystems that lead to reduced fire intensity and benefits in terms of avoidance of catastrophic fires, and vice versa. We also review the literature on tradeoffs between fire-regulating services and other ecosystem services categories.

To develop the case study, we reviewed policy and planning documents describing changes in land use and fire occurrence, including pre- and post-fire management recommendations and practices related to the Haifa-Mt. Carmel region in Israel. We then integrate information derived from expert 
lectures regarding fire management in the area, including those from focused lecture series about fire ecology, management and policy held in the immediate aftermath of large-scale fires that occurred in the region in 2010 and 2016 (the latter given in the context of a University course on fire management in urban and peri-urban areas, with additional lectures from an academic symposium on the subject held at the University of Haifa on the 7th of March 2018). The aim of this part of the study is to apply the conceptual framework developed in section Defining and Assessing FireRegulating Services and Disservices by characterizing different configurations of fire-regulating services and disservices in the region in response to changes in land use and to suggest a potential ecosystem-based approach to address fire risk in the area.

\section{The Haifa-Carmel Case Study}

We focus on the Haifa-Mt. Carmel region, a peri-urban, fireprone Mediterranean social-ecological system. Mt. Carmel is located on the Mediterranean Sea in the North of Israel $\left(32^{\circ}\right.$ $48^{\prime} 43^{\prime \prime}$ north, $34^{\circ} 59^{\prime} 55^{\prime \prime}$ east). The city of Haifa, which sits on the northwest slopes of the mount, has a population of about 281,000 inhabitants and it is the third largest city in Israel. It receives a yearly average rainfall of approximately $400 \mathrm{~mm}$, while the mean annual temperature is $19^{\circ} \mathrm{C}$ (Brand et al., 2015). The Carmel National Park, which covers an area of 10,000 hectares, is characterized by forest cover of Pinus halepensis-Pistacia palestina-Cistus sp. associations on south facing slopes and Quercus calliprinos-Pistacia palestina associations on north facing slopes (Wittenberg and Malkinson, 2009). Similar vegetation extends into the city of Haifa via a network of undeveloped wadis (dry riverbeds). To note is that most of the homogeneous Aleppo pine forest in the area is the result of intense afforestation processes, as detailed in section Changes in the Landscape of the CarmelHaifa Region.

The topography of the region, the vegetation, the climate and the wind patterns all contribute to high risk of fires (Naveh and Carmel, 2004). In the past 30 years, three large fires, in 1989, 2010, and 2016, affected the area and burned, respectively, 600, 5,000, and 2,000 ha. The 2010 fire affected principally the Carmel National Park and resulted in 44 fatalities, 250 homes destroyed, close to 20,000 people evacuated from their homes and over 5 million trees lost (Tal, 2013; Pereira et al., 2017). The 2016 fire, instead, developed almost exclusively in the urban environment, spreading throughout the city via the vegetated, dry riverbeds. It destroyed 527 apartments in 77 buildings and left 1,600 people homeless.

The case study is particularly well-suited for the identification of fire-regulating services and disservices of the coupled social-ecological system. The Haifa-Mt. Carmel region has undergone intensive transformations over time and it provides examples of a variety of fire regimes and configurations of the social-ecological system that developed in different periods due to changes in land use and forest management strategies.

\section{DEFINING AND ASSESSING FIRE-REGULATING SERVICES AND DISSERVICES}

\section{Characteristics of the Ecosystem and Management Strategies Affecting Fire-Regulating Services}

We define fire-regulating services as the benefits provided by ecosystems in terms of reduction of fire intensity, magnitude, spread, and avoidance of catastrophic fires and associated damages for human beings and the environment. We are thus interested in those ecosystem features that lead to small but recurrent fires which do not represent a threat for the environment and human beings. Conversely, ecosystems (particularly due to human interventions in the system) can introduce fire-regulating disservices and raise the likelihood of the social-ecological system to experience catastrophic fires. Ecosystem disservices are defined as "functions of ecosystems that are perceived as negative for human well-being" (Lyytimäki and Sipilä, 2009) and are often the product of environmental degradation and the disruption of ecosystems and their functioning (Balmford and Bond, 2005). In the case of fire risk, the increase of fire-regulating disservices (those defined as increased intensity, magnitude and spread of impacts leading to potential catastrophic fires) can result in increased property damage, health problems and loss of life, loss of recreation potential, loss of carbon storage in ecosystems, soil erosion, and reduced water quality, amongst other undesirable outcomes. Table 1 provides examples of ecosystem characteristics that increase fire-regulating functions of the ecosystem, leading to benefits in terms of low fire risk, and of characteristics of the ecosystem that increase the risk of catastrophic fires, leading to ecosystem disservices. In the next section we describe these characteristics of the ecosystem.

\section{Native, Fire Adapted, Low-Biomass Species}

Forest fires are an integral part of the functioning of Mediterranean ecosystems, such that their structure and function can be considered fire dependent (Naveh and Carmel, 2004; Moritz et al., 2014). This means that the vegetative composition and structure of these systems is adapted to the recurrence of fires (Pausas et al., 2008). In such ecosystems, plant and animal species flourish in post-fire conditions, and some may even decline due to fire exclusion and post-fire logging (Hutto, 1995; Noss et al., 2006). Native species in fire-prone environments generally have relatively small amounts of flammable biomass (Naveh, 1975; Tal, 2013), reducing fire risk and providing fire-regulating services. Some authors have suggested that ecosystem processes, such as biological decomposition, also reduce potential fuel for wildfires (Layke, 2009).

\section{Landscape Heterogeneity and Patchiness}

Complex landscape mosaics, patchiness and diversity in land uses are qualities that can reduce the intensity and spread of forest fires (Spies et al., 2006). For instance, the presence of patches of broadleaf, deciduous forest, amid evergreen forests, is a means to achieve more fire-resilient ecosystems and landscapes (Fernandes 
TABLE 1 | Characteristics of the (managed) ecosystem that lead to fire-regulating services and disservices.

\begin{tabular}{|c|c|}
\hline $\begin{array}{l}\text { Characteristics of ecosystems } \\
\text { providing fire-regulating services }\end{array}$ & $\begin{array}{l}\text { Characteristics of ecosystems } \\
\text { providing fire-regulating disservices }\end{array}$ \\
\hline $\begin{array}{l}\text { - Native, fire adapted, low-biomass } \\
\text { species }\end{array}$ & $\begin{array}{l}\text { - Highly flammable, high biomass, } \\
\text { invasive species }\end{array}$ \\
\hline $\begin{array}{l}\text { - Landscape heterogeneity and } \\
\text { patchiness }\end{array}$ & - Homogeneous landscape \\
\hline - Low forest density & $\begin{array}{l}\text { - High tree and canopy density and large } \\
\text { amounts of young trees }\end{array}$ \\
\hline - Fire breaks and buffers & - Continuous forest \\
\hline
\end{tabular}

et al., 2013). Sustainable and traditional agricultural activities greatly increase landscape patchiness and reduce fire spread and intensity (Badia et al., 2002). Grazing is often recommended for reducing fuel load and increases patchiness in ecosystems (Perevolotsky and Seligman, 1998; Ruiz-Mirazo and Robles, 2012; Bernués, 2017). According to Loehle (2004), even moderate degrees of diversification can significantly reduce the occurrence of catastrophic fires.

Fires themselves can enhance landscape-level patch heterogeneity (Valkó et al., 2014). The occurrence of fires at regular intervals creates a mosaic of different habitat patches and reduces the intensity of future fires (Bond and Keeley, 2005; Parks et al., 2015). Prescribed or controlled burning is an effective management strategy of the vegetation that leads to fire regulation and avoidance of catastrophic fires (Pausas and Keeley, 2019). Controlled burns, to be effective, should mimic the local fire regime as much as possible (Noss et al., 2006). Prescribed burning can also meet other conservation goals, such as the control of invasive species (Valkó et al., 2014). Note that the benefits of this practice, while offering short-term protection from potentially large fires, quickly disappear as the forest recovers and if left unmanaged (Brose and Wade, 2002). Furthermore, human induced prescribed burning reduces most fine fuels, but does not always sufficiently reduce coarse and tall fuels (Shang et al., 2004).

\section{Low Forest Density}

The main ecosystem characteristics that regulate fire extent, intensity, and occurrence are fuel loads and tree density (Reyers et al., 2015). Grazing limits shrub and herb biomass accumulation and maintains landscape heterogeneity, helping to reduce fire risk (Ruiz-Mirazo and Robles, 2012; Bernués, 2017). Heavy goat grazing of woody vegetation in the Mediterranean area is one of the most efficient management techniques for fire prevention and maintenance of habitat diversity (Perevolotsky and Seligman, 1998). It is generally used both for fuel load reduction and the maintenance of fire breaks. Advantages over technological options are that livestock disturb soils less than mechanical thinning, it has a lower risk of environmental contamination compared with herbicides, it avoids impairing air quality (occurring, for instance, through prescribed burning) and is relatively less expensive (Taylor, 2006). Grazing is also highly valued by the local population of Mediterranean agroecosystems
(Bernués et al., 2014) and by urban and peri-urban residents (Tal, 2013; Depietri and Orenstein, 2018).

Thinning, through mechanical removal of parts of the vegetation, is an effective strategy to reduce fire risk while maintaining ecosystem health (González-Olabarria and Pukkala, 2011). It can be done in multiple ways, including: reducing surface fuels to decrease potential flame length; increasing the height to live crown, which requires longer flame length to begin torching; decreasing crown density, which makes treeto-tree crown fire less probable, and; clearing vegetation while maintaining large trees of fire-resistant species, leading to less mortality for similar fire intensities (Agee and Skinner, 2005). Low ground thinning seems more effective than crown or selection thinning (Agee and Skinner, 2005). Pollet and Omi (2002) found instead that prescribed burns, whole-tree thinning, and thinning followed by prescribed burns (which removes small diameter trees) are all beneficial for reducing crown fires. By reducing forest biomass density, human activities reduce the associated risk of large fires, or, in other words, reduce the negative services or impacts associated with abundant flammable biomass. This situation is better for humans and can also increase the likelihood that the stand will survive a wildfire.

\section{Fire Breaks and Buffers}

Fire breaks and buffers (around buildings) are additional important strategies for managing ecosystems to lower fire spread and intensity. The presence of water bodies (i.e., rivers, lakes, ice, and snow), grassland corridors, gravel beds, areas with sparse plant growth and other elements of discontinuity in the ecosystem, such as areas with less flammable broadleaf forest, generate ("natural") fire breaks and buffers which block or slow down the advancement of fires. But while fuel breaks might be effective in slowing down the spread of a fire, they do not extinguish it (Loehle, 2004). Another drawback is that the heavy equipment required in the case of mechanical removal of the vegetation in human-made fire breaks disturbs the soil, contributes to erosion and can cost hundreds of dollars per acre (Taylor, 2006).

\section{Characteristics of Ecosystems and Mismanagement Leading to Fire-Regulating Disservices}

Particular changes in forest structure may lead to catastrophic or mega-fires (Stephens et al., 2014), causing damages to people, buildings, infrastructures and ecosystems. Diverse ecosystem features and activities, that have been shown to increase the risk of catastrophic fires, are summarized in Table $\mathbf{1}$ and include: land abandonment (including the reduction of pastoral activities driven by rural depopulation); the homogenization of the landscape; changes in the vegetation composition, such as through the introduction of highly flammable invasive species; large-scale afforestation; fire suppression, which leads to high density of trees; strict ecosystem conservation, which leads to high canopy density and a large amount of young trees (MacDonald et al., 2000; Badia et al., 2002; Agee and Skinner, 2005; Pausas et al., 2008; Martínez et al., 2009; Fernandes et al., 2013; Bernués, 2017; Bond and Keane, 2017). Most of these 
features lead to increased fire risk, high impacts and are a (often undesired) product of human activities.

\section{Highly Flammable, High Biomass Invasive Species}

Non-native invasive trees, especially when located in and around urban and peri-urban areas, can greatly increase the risk of fires (Reyers et al., 2015). Exotic tree species, with abundant aboveground biomass (i.e., fuel) and horizontal or vertical continuity, can increase fire intensity (Brooks et al., 2004; Nel et al., 2014). Invasive grasses can also lead to greater fire frequency and intensities, and encourage negative feedback loops which reduce the recruitment of native species and enhance that of the invasive ones (Rossiter et al., 2003; Gaertner et al., 2014). Invasive species can indeed change fire regimes and initiate fire cycles that are difficult to break (Brooks et al., 2004; Wagner and Fraterrigo, 2015). In arid ecosystems, the interaction between fire and invasive species may lead to more frequent and intense fires that reduce the fertility and productivity of these areas (Higgins et al., 1997). Invasive weeds, such as wild sage (Lantana camara), have been documented to increase fire intensity in dry rainforests (Berry et al., 2011). Invasive fire-prone woody plants or plants with highly flammable leaves can have similar effects (Beest et al., 2012; Murray et al., 2013). For instance, pine trees of different species, often introduced through afforestation efforts, generally increase fire risk (Richardson and Wilgen, 2004). The construction of fire breaks can themselves, if left unmanaged, facilitate the spread of such flammable invasive species (Keeley, 2001).

\section{Homogenous, Continuous Landscapes, and High Forest Density}

Ecosystems that are susceptible to catastrophic fires which bring significant damage to people, infrastructures and ecosystems (or fire-regulating disservices) are generally ecosystems in which landscape diversity and natural disturbances are suppressed. An increase in fire-regulating disservices is often a direct or indirect consequence of human activities. While fireregulating services are strongest in diverse ecosystems with moderate disturbance regimes (e.g., recurrent small fires), the suppression of disturbances generates fire-regulating disservices. Homogeneous and continuous landscapes with high forest density, formed due to land abandonment, fire suppression activities and strict conservation or afforestation, can lead to an increased risk of catastrophic fires (Azevedo et al., 2011). The presence of high density and continuous coniferous forests, for instance, can lead to fires with high intensity and magnitude, likely to cause significant damages. High canopy density also leads to crown fires that are difficult to control, often leading to catastrophic impacts (Mitsopoulos and Dimitrakopoulos, 2007).

\section{Trade-Offs Between Fire-Regulating Services and Other Ecosystem Services}

There are trade-offs between fire-regulating services and other services provided by ecosystems. According to Fernandes et al. (2013), no single fire regime is optimal or even beneficial for all ecosystems. For example, thinning reduces fire risk, but also reduces climate-regulating services through the reduction of standing biomass (capable of carbon storage). However, it is also documented that ecosystems have experienced an increase in the amount of $\mathrm{CO}_{2}$ released due to the policy of fire suppression, which leads to build-up of fuel. In these conditions, the fire, when it occurs, is of higher intensity and leads to a higher amount of biomass burned, releasing more $\mathrm{CO}_{2}$ than a typical forest fire would (Hurteau et al., 2008; Mitchell et al., 2009; Daigneault et al., 2010). According to Mitchell et al. (2009), balancing demand for landscape carbon storage with the demand for reduced wildfire severity might require treatments to be applied strategically throughout the landscape rather than treating all stands indiscriminately.

Wildfires interfere with other services, such as soil erosion regulation, the provision of clean drinking water, and the preservation of aquatic biodiversity (Fernandes et al., 2013). Prescribed forest fires might in fact lead to a temporary increase in soil erosion. Fires leave the soil unprotected and intensify runoff, which leads to soil losses in the aftermath of a fire event (Wittenberg and Inbar, 2009). Excessive and heavy grazing, thinning and the construction of fire breaks can increase runoff and soil erosion. Ashes and fire from prescribed burning may temporarily affect water quality (and thus water supply) and environmental health, leading to a temporary loss of biodiversity. The aesthetical and recreational value of ecosystems can be also temporarily affected by prescribed burning.

\section{Assessing Fire-Regulating Services and Disservices}

Tables 2, 3 list possible proxies to assess, in biophysical terms, fire characteristics of the ecosystem leading to fire-regulating services and disservices. While these lists are not exhaustive, they provide a basis for ecosystem assessment about fire-regulating services and disservices. Prevented or potential damages and losses can in fact be linked to ecosystem features that determine fire risk. Specific species compositions, for example, can be associated to a decrease or to an increase in fire intensity, magnitude and spread, and thus to potential impacts. These measurements can thus serve as biophysical proxies for fire-regulating services or disservices. An example is provided by Sil et al. (2019), who include the types of forest trees in their simulations of fire risk. This represents a step to associate ecosystem features and structures to avoided or potential damages and losses. This is a fundamental step toward assessing alternative ecosystem states and their potential for preventing or facilitating ecosystem damages (i.e., fire-regulating services or disservices).

The formulation of the benefits provided by ecosystems in terms of fire-regulation opens a door for monetary and non-monetary valuation of services. Despite the numerous controversial aspects of ecosystem services valuation (Kosoy and Corbera, 2010; Gómez-Baggethun and Ruiz-Pérez, 2011; Kallis et al., 2013), this practice has advantages in terms of rendering visible to economic accounting the benefits that certain ecosystem features and management strategies can bring in terms of reduced fire risk. While being only a layer of the decisionmaking process, economic valuation can in fact support and 
TABLE 2 | List of characteristics of ecosystems that provide fire-regulating services and biophysical proxies to assess them.

\section{Characteristics of the ecosystem Biophysical proxies}

providing fire-regulating services

Native, fire adapted, low biomass species

Landscape heterogeneity and patchiness

Low forest density

Fire breaks and buffers
Type of vegetation and its flammability

Patch size distribution, i.e., the number of patches of individuals of the same species as a function of their size (Kéfi et al., 2007) Area (intentionally) burned (ha)

Density of the forest (trees per ha)

Number, distribution and spatial extent of fire breaks (ha)

TABLE 3 | List of characteristics of ecosystems that produce fire-regulating disservices and biophysical proxies to assess them.

\section{Characteristics of the ecosystem providing fire-regulating disservices \\ Highly flammable, high biomass, invasive species Homogenization of the landscape}

High tree density and large amounts of young trees

Continuous forest

Density of forest (trees per ha)

Continuous forest area (ha)
Landscape uniformity (ha) Protected area which excludes human activities such as herding (ha)

Area in which fire suppression has been performed (ha)

Forest age (average trees age in years)

strengthen ecosystem-based approaches to disaster risk reduction by providing additional justifications for their adoption.

Assessing fire-regulating ecosystem services in economic terms can be done, for instance, by measuring the avoided damage cost (de Groot et al., 2002). Fire-regulating services should be valued at least as much as the cost society would incur if fire damages were not avoided. Replacement cost or substitute cost methods are also relevant for estimating values of fire-regulating services (Farber et al., 2002). The replacement cost method determines whether property owners have spent money to protect their property (i.e., through insurance or by fireproofing the house through, for instance, fire retardant paints). The method uses these avoidance expenditures to estimate fire-regulating services. Replacement or substitute cost methods are used to estimate the costs of providing a substitute for the degraded or lost services (TEEB, 2012). Overall, these methods are based on the cost of replacing the services (or on the cost of providing substitutes for the services) of reduced risk. Note that all these measurements refer mainly to damages to infrastructures, buildings, other man-made capital and only partially to the environment and human beings. Loss of human life and species is ethically and practically challenging to translate into economic terms.

\section{Conceptual Framework}

Based on the literature reviewed above, we developed the conceptual framework presented in Figure 1. The framework illustrates how fire hazard can be mitigated by certain ecosystem characteristics which can either increase or decrease the intensity and extent of fires. These ecosystem characteristics are often coproduced by (intended or unintended) human interactions with the natural landscape. Resultant fires impact the social systemmore intensely or less-, which then responds (or not) to losses, thereby determining the supply of fire-regulating services or disservices. Changes in the social-ecological system also directly determine chances of fire ignition and fire intensity, thereby closing the feedback cycle.

\section{AN APPLICATION TO THE HAIFA-CARMEL CASE STUDY}

\section{Changes in the Landscape of the Carmel-Haifa Region}

The landscape of Mt. Carmel has been modified and extensively and intensively managed since prehistoric times (Naveh and Carmel, 2004). The historical vegetation composition was characterized by Quercus calliprinos, Pistacia palestina, Pistacia lentiscus typicum, Ceratonieto, and Olea europaea (Naveh, 1973; Danin, 1988). These species are scrub-like in Mediterranean ecosystems, with relatively low biomass for trees, and are adapted to fires (Naveh, 1975). Prevalence of these locally adapted species reduce the risk of catastrophic fires due to their low biomass and low flammability, leading to benefits to the population and the environment in terms of reduced extreme fire impacts (fireregulating services).

In the past thousand years, the region's forests were decimated by wars, overgrazing, harvesting for fuel and by forest fires (Amir and Rechtman, 2006; Tal, 2016). Only some areas of the Carmel forest survived the extirpation of most of the region's forests during the Ottoman rule, which concluded at the beginning of the twentieth century (Tal, 2013). During this period the risk of wildfire diminished greatly, but the environment was largely overexploited and potentially degraded.

Logging and livestock grazing in the area was stopped only during the British mandate (1923-1948), as the British government perceived that the practices were bringing widespread environmental devastation. After 1948, Israeli land managers also adopted an anti-grazing bias (Tal, 2013). This bias was reflected in the legislation preventing livestock grazing on public lands, including forests and rangelands (i.e., "The Black Goat Law" of 1950) (Safriel, 1997; Perevolotsky and Seligman, 1998). Exclusion of grazing on public land has been suggested to have contributed to increased fire risk, as it produced fire-regulating disservices. While goat grazing pressure was reduced, the density of the remaining woody vegetation increased (Carmel and Kadmon, 1999), and the forest and shrub cover became thicker, which made it impenetrable to humans and highly flammable (Tal, 2013). Although grazing is no longer opposed by land use agencies, it has not been fully reintroduced in the area (Pereira et al., 2017). 


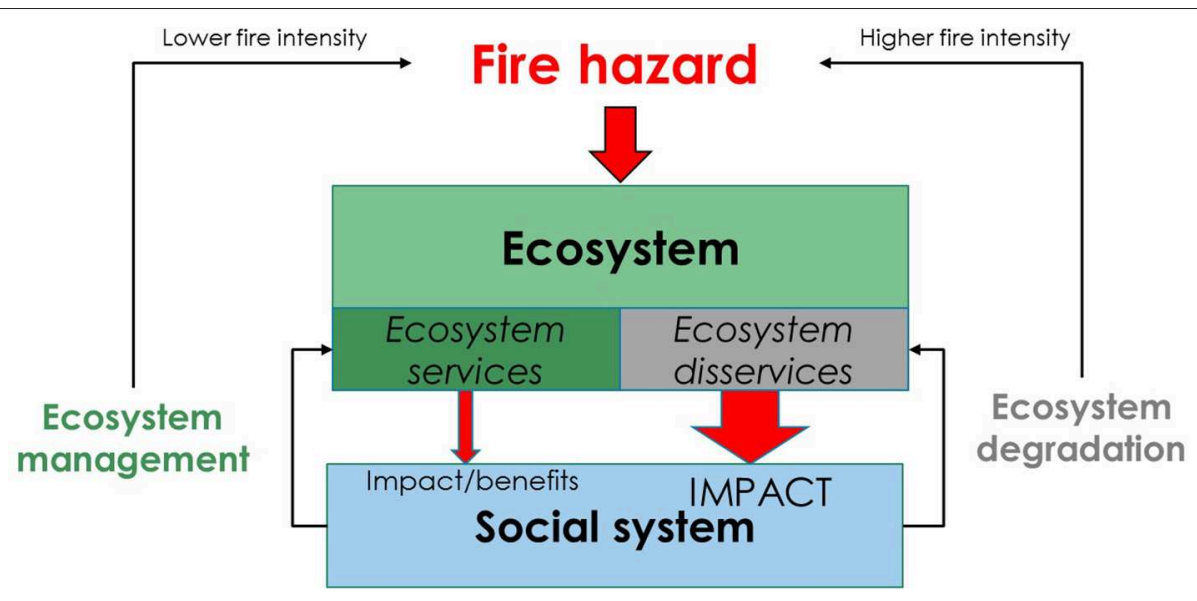

FIGURE 1 | Conceptual framework summarizing interactions between the hazard and the social-ecological system. Although social and ecological systems are integrated with one another, here are maintained separately for graphical clarity.

Parallel to grazing trends, at the end of the nineteenth century, entire areas of Mt. Carmel were re-forested by the German Templers (Kaplan, 2011). This practice was adopted and maintained by the Keren Kayemeth LeIsrael (KKL or the Jewish National Fund-JNF), who became the de facto national forest service following the establishment of Israel in 1948. Most of the forests on Mt. Carmel and elsewhere are the result of these historical afforestation efforts (Ne'eman et al., 1997). More than $50 \%$ of the forests in Israel were planted with coniferous trees, the most common of which was the Aleppo pine (Pinus halepensis). The choice of this species was primarily due to the desire to reproduce green and thick forests reminiscent of European landscapes (Amir and Rechtman, 2006; Kaplan, 2011). It was also thought that pine trees were particularly well-suited to the local climate, requiring minimal care (Stemple, 1998).

Pinus halepensis, however, is a very flammable species characterized by a pronounced ability to regenerate via seeds after fires (Ne'eman et al., 2004). This quality defines its invasive nature. Planted forests were also uniform, dense, monocultured and even-aged, all characteristics which increase the risk of forest fires (Amir and Rechtman, 2006; Osem et al., 2008). The history of the afforestation of Israel and the Carmel Forest is thus one of introduction of highly flammable, largely allochthonous species, which was driven mainly by a landscape aesthetic inspired from more mesic ecosystems in Europe (Osem et al., 2008). In this way, afforestation using coniferous species produced catastrophic fires (e.g., in 2010) leading to impacts on the population and the environment (fire-regulating disservices).

More recently, nature preservation practices, which exclude most human agro-pastoral activities and limit the active management of the forest, coupled with an expanding tourist infrastructure, including scenic routes, footpaths and hiking trails, have further exposed forests in the Haifa-Mt. Carmel region to the risk of catastrophic fires (Carmel et al., 2009; Tal, 2013). A strict nature conservation approach, which tends to exclude human agropastoral activities from forested areas, including grazing, produces a dense and thick forest and has caused catastrophic fires (or fire-regulating disservices) (Pereira et al., 2012).

\section{Fire Risk Management in the Haifa-Carmel Region Since the 1990s}

After the two major Carmel fires in 1989 and 2010, expert committees were assembled to develop and assess management options to reduce fire risk in the region. Experts committees, convened after each fire event, came to similar conclusions regarding the fire prevention strategies to be adopted. These mainly concerned the need to dedicate more resources to ecosystem management in the Carmel area, principally addressing fuel loads and landscape diversity. When the expert committee was assembled to provide post-2010 fire recommendations, it explained that their recommendations were nearly identical to those offered following the 1989 fire (Perevolotsky, 2011; Pereira et al., 2017).

Some of the recommendations included in the reports produced by the post-1989 and 2010 fires commissions of enquiry were: the elimination of understory vegetation by prescribed burns and herbicides; pruning of lower branches to prevent fire from climbing to the crown; development of fire breaks and buffers along buildings and roads; planting of less flammable tree species (including oaks, cypress and carob or groves of fruit trees); the removal of pine trees; forest thinning; the removal of biomass residue from various fire management activities, and; constructing roads into the forest to improve access for firefighters (Safriel, 1997; Perevolotsky, 2011; Tal, 2013). Overall these strategies can be considered as ecosystem management that would encourage characteristics of the ecosystem that reduce likelihood of catastrophic fire and thus provide fire-regulating services.

However, between 1989 and 2010, ecosystem-based fire management strategies were only partially implemented, despite nearly unanimous support among experts. The scientific report prepared in the aftermath of the 2010 fire clearly stated that the central problem concerning fire risk is the lack of the implementation of the recommendations, particularly regarding 
the management of forest and shrubland (Perevolotsky, 2011). The post-fire activities implemented were criticized, primarily for their lack of consistency with the recommendations. For instance, management plans did not support the reduction of the high biomass, high risk Aleppo pine forests. When firebreaks were developed, they were not adequately maintained by the Nature and Parks Authority and little was done about thinning and pruning (Tal, 2013). The 1995 Israeli National Master Plan for Forests and Afforestation (NOP 22), written after the 1989 Carmel Fire, merely cites the issue of forest fires in a short paragraph with no mention about the need to improve the management of the afforested land to prevent forest fires (Kaplan, 2011). To date, a clear ecosystem-based management approach to fire risk reduction in Israel has not been adopted.

The approach for dealing with forest fires in the Carmel area, and in Israel in general, continues to focus primarily on strengthening fire-fighting capacity. A lack of consistent forest management practices in the Carmel National Park has led to the proliferation of invasive species of trees, accumulation of organic matter (potentially leading to increased fire risk or ecosystem disservices). However, despite the incomplete implementation of ecosystem approaches, government funding continues to be dedicated to post-fire research, preparedness and restoration, particularly following catastrophic fires. By not intervening in the forest, and by focusing resources primarily on fire suppression, the catastrophic fire risk on Mt. Carmel area is only perpetuated.

Recently, some progress in this regard is being made. Most of the newly planted forests in Israel take into account fire risk and their management is commensurate with the recommendations given by the post-1989 and post-2010 Carmel fire expert committees (Tal, 2013). Since the 1990s, afforestation efforts have tried to combine a variety of forest types associated with various habitat conditions (Amir and Rechtman, 2006). After the 2010 fire that affected the Carmel, replanting was dominated by broadleaf and indigenous species and funding was allocated for developing firebreaks and vegetation thinning (Tal, 2013). But these interventions remain insufficient and the funds collected by KKL are dedicated only partly to replanting efforts (due to the recommendations by experts to leave the forest to natural regeneration), and have been used instead to enlarge the firefighting fleet (Tal, 2013).

The case study clearly shows how the ecosystem characteristics leading to ecosystem services or disservices in the case of fire regulation are generally co-produced by human activities.

A companion paper has analyzed trade-offs between fireregulating services and cultural services (such as recreation, educational activities and aesthetic values) in Haifa, Israel, documenting how these trade-offs may arise in the case study area. Managing the peri-urban ecosystem to reduce fire risk, on the one hand, and facilitating the desire to keep the forest as "natural" or untouched as possible on the other, can interfere and generate conflicts (Depietri and Orenstein, 2018).

\section{Synthesis of Interactions Between Fire Risk and the Changing Social-Ecological System in the Haifa-Carmel Region}

We visualize the interactions between land use management, changes in fire occurrence and fire-regulating services or disservices in the context of the Haifa -Mt. Carmel area in Figure 2. The figure illustrates the multiple interactions occurring due to changes in land-uses in the area, different degrees of human intervention leading to changes in fireregulating services and disservices, and changes in the fire occurrence.

The right side of the figure depicts the extreme situation when the Haifa-Mt. Carmel region underwent periods of intensive exploitation and overgrazing (e.g., during the Ottoman rule). In this period, although human activities and ecosystem interventions reduced (or even extinguished) the risk of fire, the same activities produced an undesirable situation of overexploitation and environment degradation. The extreme left side of the figure represents the subsequent, extended period of intensive afforestation (with the creation of dense and homogeneous Aleppo pine forests) which comprised a combination of intensive human intervention then coupled with strict environmental conservation (exclusion of agricultural activities and grazing from protected areas). This combination of management decisions increased the fuel load and density, producing increased fire risk and impacts (i.e., fire-regulating disservices). The natural environment has not been pristine (or "natural" with no human interventions) since prehistoric times. Humans are now a permanent fixture on the landscape, and so sustainable management through an ecosystem-based approach must entail a mix of human activities that focus on managing for ecosystem characteristics that reduce fire risk promoting fireregulating services. This represents the desirable situation that planners, landscape managers and foresters should aim for.

\section{DISCUSSION}

We defined fire-regulating services and disservices by extensively reviewing the literature related to the ecosystem features and the management strategies that decrease or increase the risk of catastrophic fires. Defining and assessing fire-regulating services and disservices by identifying and measuring the links between ecosystem characteristics and fire risk is an important starting point for designing effective ecosystem-based approaches for fire risk reduction. Ecosystem-based approaches are consistently recommended by expert committees and have been shown to be effective in reducing risk in multiple contexts (Renaud et al., 2013). In the context of fire risk, the production of fire-regulating services needs continuous inputs of human capital, not only to produce them initially, but also to maintain their provision in the long term. This means that adequate budgets and consistency in management are required.

As illustrated by the Haifa-Mt. Carmel case, it is challenging to concurrently maintain ecosystem integrity, allow diverse human activities and minimize fire risk. The desirable situation is that of sustainable management of the ecosystem that enhances fireregulating services. This can be achieved through reintroducing grazing, practicing thinning, developing and maintaining firebreaks and the planting of low-biomass locally adapted species. Fire-regulating services can increase with human intervention, although intervention can also be excessively intensive, threatening ecosystem integrity (Figure 2). In the case of the Haifa-Mt. Carmel region, the period of intensive 


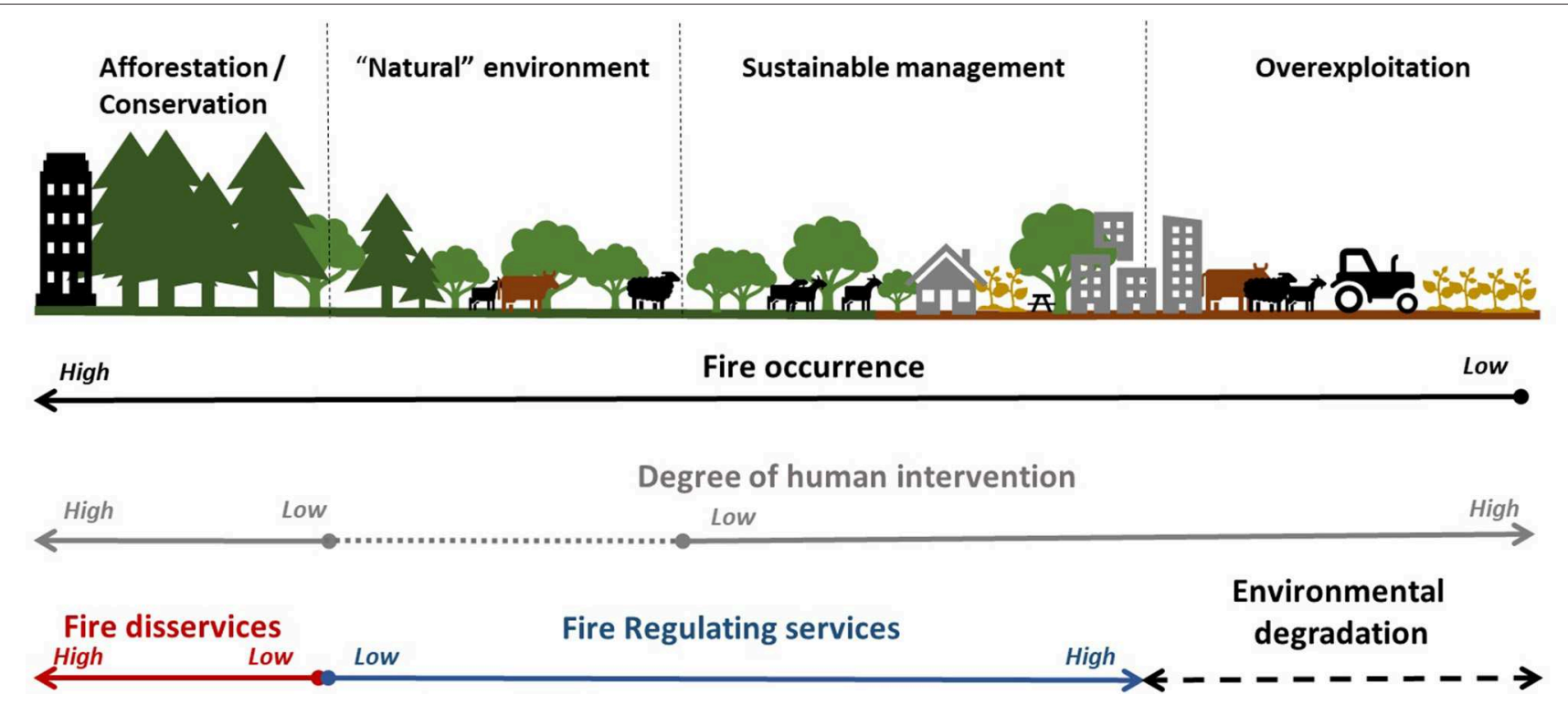

FIGURE 2 | Interactions between types of land use, the risk of forest fires, the degree of human intervention, the availability of fire-regulating services disservices which occurred, are occurring or should occur in the Haifa-Carmel region.

overgrazing and logging surely lowered the fire risk, but it also produced an undesirable situation of environmental degradation. In order to be beneficial overall, fire prevention management should produce less damage to the ecosystem than a catastrophic fire itself would cause. At the other extreme, land abandonment, excessive nature conservation that restricts human activities from forested areas, and intense afforestation, can lead to biomass accumulation potentially feeding megafires with catastrophic impacts, producing fire-regulating disservices.

An important caveat: urban planning is another important human factor at play in fire risk, particularly at the WUI where urban sprawl has significantly increased fire risk in Mediterranean areas (Mell et al., 2010; Modugno et al., 2016). In areas of sprawl (low-density residential development), the WUI widens, structures and vegetation are intermingled and the proximity of new structures to the forest also increases (Badia et al., 2011). All of these conditions increase exposure to fire risk while further rendering difficult the work of firefighters (LampinMaillet et al., 2010). Under conditions of urban sprawl, ecosystem management alone will not be able to adequately compensate for increased risk in these sensitive areas.

\section{CONCLUSIONS}

The lack of definition of fire-regulating services and disservices represents a major gap in the ecosystem services literature. This hampers biophysical and economic valuations that might contribute to the design and implementation of effective ecosystem-based approaches for fire risk reduction.

We offer our definition of fire-regulating services: those benefits resulting from specific, co-produced ecosystem features and ecosystem management, that prevent the social-ecological system from experiencing impacts from catastrophic fires.
We also define, vice versa, fire-regulating disservices as those which increase the potential for catastrophic fires affecting people, buildings, infrastructures and ecosystems, which can be linked to unfavorable ecosystem features, often produced by environmental degradation and ecosystem mismanagement. We then provide a list of biophysical proxies for assessing ecosystem characteristics linked to fire intensity and spread and potentially leading to fire-regulating services and disservices. We also provide a conceptual framework depicting the interactions between the hazard, the ecosystem and the social system.

To apply these concepts, we analyzed the historical development of the social-ecological system and the changes in fire regimes in the Haifa-Mt. Carmel region and we identified when and how the system provided fire-regulating services or disservices. We also looked at forest management practices that should be adopted in the area to reduce fire risk today. The region went through different development phases that affected fire regimes and, by analyzing them, we identified distinct conditions of the social-ecological system that lead to producing fire-regulating services or disservices. A period of overexploitation was followed by intensive afforestation and by managerial neglect, which inadvertently increased the risk of forest fires by enhancing the characteristics of the ecosystem that lead to ecosystem disservices. Restoring fire-adapted vegetative communities, combined with moderate to low-impact human activities can reduce the risk of incurring in catastrophic fires and lead to a higher provision of fire-regulating services.

Fire-regulating services in human-modified environments or social-ecological systems are often co-produced by different types of capital. From the literature review and from an analysis of the experience dealing with fires on Mt. Carmel, we conclude that risk reduction, via improved regulating services, necessitates active ecosystem management within social-ecological systems. 


\section{AUTHOR CONTRIBUTIONS}

YD designed the research in collaboration with DO. YD collected the information and was the primary writer. DO also contributed to the writing.

\section{REFERENCES}

Agee, J. K., and Skinner, C. N. (2005). Basic principles of forest fuel reduction treatments. For. Ecol. Manag. 211, 83-96. doi: 10.1016/j.foreco.2005.01.034

Amir, S., and Rechtman, O. (2006). The development of forest policy in Israel in the 20th century: implications for the future. For. Policy Econ. 8, 35-51. doi: 10.1016/j.forpol.2004.05.003

Azevedo, J. C., Moreira, C., Castro, J. P., and Loureiro, C. (2011). “Agriculture abandonment, land-use change and fire hazard in mountain landscapes in Northeastern Portugal," in Landscape Ecology in Forest Management and Conservation, eds C. Li, R. Lafortezza, and J. Chen (Berlin; Heidelberg: Springer Berlin Heidelberg), 329-351.

Badia, A., Sauri, D., Cerdan, R., and Llurdés, J.-C. (2002). Causality and management of forest fires in Mediterranean environments: an example from Catalonia. Glob. Environ. Change Part B Environ. Hazards 4, 23-32. doi: 10.1016/S1464-2867(02)00014-1

Badia, A., Serra, P., and Modugno, S. (2011). Identifying dynamics of fire ignition probabilities in two representative Mediterranean wildland-urban interface areas. Appl. Geogr. 31, 930-940. doi: 10.1016/j.apgeog.2011.01.016

Balmford, A., and Bond, W. (2005). Trends in the state of nature and their implications for human well-being. Ecol. Lett. 8, 1218-1234. doi: 10.1111/j.1461-0248.2005.00814.x

Beest, M., Cromsigt, J. P. G. M., Ngobese, J., and Olff, H. (2012). Managing invasions at the cost of native habitat? An experimental test of the impact of fire on the invasion of Chromolaena odorata in a South African savanna. Biol. Invasions 14, 607-618. doi: 10.1007/s10530-0110102-z

Bernués, A. (2017). "Animals on the land. Ecosystem services and disservices of grazing livestock systems," in The Meat Crisis: Developing more Sustainable and Ethical Production and Consumption, eds J. D'Silva and J. Webster (London), 26.

Bernués, A., Rodríguez-Ortega, T., Ripoll-Bosch, R., and Alfnes, F. (2014). Socio-cultural and economic valuation of ecosystem services provided by mediterranean mountain agroecosystems. PLoS ONE 9:e102479. doi: 10.1371/journal.pone.0102479

Berry, Z. C., Wevill, K., and Curran, T. J. (2011). The invasive weed Lantana camara increases fire risk in dry rainforest by altering fuel beds. Weed Res. 51, 525-533. doi: 10.1111/j.1365-3180.2011.00869.x

Blanchard, B., and Ryan, R. L. (2007). Managing the wildland-urban interface in the northeast: perceptions of fire risk and hazard reduction strategies. North. J. Appl. For. 24, 203-208. doi: 10.1093/njaf/24.3.203

Bond, W. J., and Keane, R. E. (2017). "Fires, ecological effects of," in Reference Module in Life Sciences, ed S. A. Levin (Elsevier), 1-11 Available online at: https://www.sciencedirect.com/referencework/9780123847201/encyclopediaof-biodiversity\#book-description

Bond, W. J., and Keeley, J. E. (2005). Fire as a global 'herbivore': the ecology and evolution of flammable ecosystems. Trends Ecol. Evol. 20, 387-394. doi: 10.1016/j.tree.2005.04.025

Bowman, D. M. J. S., Balch, J., Artaxo, P., Bond, W. J., Cochrane, M. A., D’Antonio, C. M., et al. (2011). The human dimension of fire regimes on Earth. J. Biogeogr. 38, 2223-2236. doi: 10.1111/j.1365-2699.2011.02595.x

Boyd, J., and Banzhaf, S. (2007). What are ecosystem services? The need for standardized environmental accounting units. Ecol. Econ. 63, 616-626. doi: 10.1016/j.ecolecon.2007.01.002

Braat, L. C., and de Groot, R. (2012). The ecosystem services agenda: bridging the worlds of natural science and economics, conservation and development, and public and private policy. Ecosyst. Serv. 1, 4-15. doi: 10.1016/j.ecoser.2012.07.011

\section{FUNDING}

This research was supported by a grant from the Israel Science Foundation (Grant No. 1835/16) and a Zeff Postdoctoral Fellowship at the Technion.

Brand, D., Moshe, I., Shaler, M., Zuk, A., and Riov, J. (2015). Afforestation in IsraelReclaiming Ecosystems and Combating Desertification. Department of Forestry, Keren Kayemeth LeIsrael-Jewish National Fund.

Brockerhoff, E. G., Barbaro, L., Castagneyrol, B., Forrester, D. I., Gardiner, B., González-Olabarria, J. R., et al. (2017). Forest biodiversity, ecosystem functioning and the provision of ecosystem services. Biodivers. Conserv. 26, 3005-3035. doi: 10.1007/s10531-017-1453-2

Brooks, M. L., D’antonio, C. M., Richardson, D. M., Grace, J. B., Keeley, J. E., Ditomaso, J. M., et al. (2004). Effects of invasive alien plants on fire regimes. Bioscience 54, 677-688. doi: 10.1641/0006-3568(2004)054[0677:EOIAPO]2.0. $\mathrm{CO} ; 2$

Brose, P., and Wade, D. (2002). Potential fire behavior in pine flatwood forests following three different fuel reduction techniques. For. Ecol. Manag. 163, 71-84. doi: 10.1016/S0378-1127(01)00528-X

Burkhard, B., and Maes, J. (2017). Mapping Ecosystem Services. Sofia: Pensoft Publishers, 374.

Caldararo, N. (2002). Human ecological intervention and the role of forest fires in human ecology. Sci. Total Environ. 292, 141-165. doi: 10.1016/S0048-9697(01)01067-1

Campagne, C. S., and Roche, P. (2018). May the matrix be with you! Guidelines for the application of expert-based matrix approach for ecosystem services assessment and mapping. One Ecosyst. 3:e24134. doi: 10.3897/oneeco.3.e24134

Carmel, Y., and Kadmon, R. (1999). Effects of grazing and topography on longterm vegetation changes in a Mediterranean ecosystem in Israel. Plant Ecol. 145, 243-254. doi: 10.1023/A:1009872306093

Carmel, Y., Paz, S., Jahashan, F., and Shoshany, M. (2009). Assessing fire risk using Monte Carlo simulations of fire spread. For. Ecol. Manag. 257, 370-377. doi: 10.1016/j.foreco.2008.09.039

Cohen, J. (2008). The Wildland-Urban Interface Fire Problem: A Consequence of the Fire Exclusion Paradigm. Forest History Today, 20-26.

Costanza, R. (2008). Ecosystem services: multiple classification systems are needed. Biol. Conserv. 141, 350-352. doi: 10.1016/j.biocon.2007.12.020

CRED (2019). 2018: Extreme Weather Events Affected 60 Million People. Brussels: United Nations Office for Disaster Risk Reduction (UNISDR) and Center for Research on the Epidemiology of Disasters (CRED).

Daigneault, A. J., Miranda, M. J., and Sohngen, B. (2010). Optimal forest management with carbon sequestration credits and endogenous fire risk. Land Econ. 86, 155-172. doi: 10.3368/le.86.1.155

Daily, G. (1997). Nature's Services: Societal Dependence on Natural Ecosystems. Washington, DC: Island Press.

Danin, A. (1988). Flora and vegetation of Israel and adjacent areas. Zoogeography Isr. 30, 251-276.

de Groot, R. S., Alkemade, R., Braat, L., Hein, L., and Willemen, L. (2010). Challenges in integrating the concept of ecosystem services and values in landscape planning, management and decision making. Ecol. Complex. 7, 260-272. doi: 10.1016/j.ecocom.2009.10.006

de Groot, R. S., Wilson, M. A., and Boumans, R. M. J. (2002). A typology for the classification, description and valuation of ecosystem functions, goods and services. Ecol. Econ. 41, 393-408. doi: 10.1016/S0921-8009(02)00089-7

Depietri, Y., Kallis, G., Baró, F., and Cattaneo, C. (2016). The urban political ecology of ecosystem services: the case of Barcelona. Ecol. Econ. 125, 83-100. doi: 10.1016/j.ecolecon.2016. 03.003

Depietri, Y., and McPhearson, T. (2017). "Integrating the grey, green, and blue in cities: nature-based solutions for climate change adaptation and risk reduction," in Nature-Based Solutions to Climate Change Adaptation in Urban Areas Theory and Practice of Urban Sustainability Transitions, eds N. Kabisch, H. Korn, J. Stadler, and A. Bonn (Cham: Springer), 91-109. 
Depietri, Y., and Orenstein, D. E. (2018). Tradeoffs between regulating and cultural services as a sources of fire risk in Haifa. in Conference Proceedings - Long Paper (Barcelona).

Díaz, S., Demissew, S., Carabias, J., Joly, C., Lonsdale, M., Ash, N., et al. (2015). The IPBES conceptual framework - connecting nature and people. Curr. Opin. Environ. Sustain. 14, 1-16. doi: 10.1016/j.cosust.2014.11.002

Ernstson, H. (2013). The social production of ecosystem services: a framework for studying environmental justice and ecological complexity in urbanized landscapes. Landsc. Urban Plan. 109, 7-17. doi: 10.1016/j.landurbplan.2012.10.005

Farber, S. C., Costanza, R., and Wilson, M. A. (2002). Economic and ecological concepts for valuing ecosystem services. Ecol. Econ. 41, 375-392. doi: 10.1016/S0921-8009(02)00088-5

Fernandes, P. M., Davies, G. M., Ascoli, D., Fernández, C., Moreira, F., Rigolot, E., et al. (2013). Prescribed burning in southern Europe: developing fire management in a dynamic landscape. Front. Ecol. Environ. 11, e4-e14. doi: $10.1890 / 120298$

Fisher, B., and Turner, K. R. (2008). Ecosystem services: classification for valuation. Biol. Conserv. 141, 1167-1169. doi: 10.1016/j.biocon.2008.02.019

Fisher, B., Turner, R. K., and Morling, P. (2009). Defining and classifying ecosystem services for decision making. Ecol. Econ. 68, 643-653. doi: 10.1016/j.ecolecon.2008.09.014

Foley, J. A., DeFries, R., Asner, G. P., Barford, C., Bonan, G., Carpenter, S. R., et al. (2005). Global consequences of land use. Science 309, 570-574. doi: $10.1126 /$ science. 1111772

Gaertner, M., Biggs, R., Beest, M. T., Hui, C., Molofsky, J., and Richardson, D. M. (2014). Invasive plants as drivers of regime shifts: identifying highpriority invaders that alter feedback relationships. Divers. Distrib. 20, 733-744. doi: 10.1111/ddi.12182

Gómez-Baggethun, E., and Ruiz-Pérez, M. (2011). Economic valuation and the commodification of ecosystem services. Prog. Phys. Geogr. Earth Environ. 35, 613-628. doi: 10.1177/0309133311421708

González-Olabarria, J.-R., and Pukkala, T. (2011). Integrating fire risk considerations in landscape-level forest planning. For. Ecol. Manag. 261, 278-287. doi: 10.1016/j.foreco.2010.10.017

Grimm, N., Cook, E. M., Hale, R. L., and Iwaniec, D. M. (2016). “A broader framing of ecosystem services in cities: benefits and challenges of built, natural, or hybrid system function," in The Routledge Handbook of Urbanization and Global Environmental Change, eds K. C.-Y. Seto, W. Solecki, and C. Griffith (New York, NY: Routledge, Taylor and Francis Group), 203-212.

Haines-Young, R., and Potschin, M. (2018). Common International Classification of Ecosystem Services (CICES) V5.1. Guidance on the Application of the Revised Structure. Nottingham: Fabis Consulting Ltd.

Harper, A. R., Doerr, S. H., Santin, C., Froyd, C. A., and Sinnadurai, P. (2018). Prescribed fire and its impacts on ecosystem services in the UK. Sci. Total Environ. 624, 691-703. doi: 10.1016/j.scitotenv.2017.12.161

Higgins, S. I., Turpie, J. K., Costanza, R., Cowling, R. M., Le Maitre, D. C., Marais, C., et al. (1997). An ecological economic simulation model of mountain fynbos ecosystems: dynamics, valuation and management. Ecol. Econ. 22, 155-169. doi: 10.1016/S0921-8009(97)00575-2

Hurteau, M. D., Bradford, J. B., Ful,é, P. Z., Taylor, A. H., and Martin, K. L. (2014). Climate change, fire management, and ecological services in the southwestern US. For. Ecol. Manag. 327, 280-289. doi: 10.1016/j.foreco.2013.08.007

Hurteau, M. D., Koch, G. W., and Hungate, B. A. (2008). Carbon protection and fire risk reduction: toward a full accounting of forest carbon offsets. Front. Ecol. Environ. 6, 493-498. doi: 10.1890/070187

Hutto, R. L. (1995). Composition of Bird Communities following standreplacement fires in northern rocky mountain (U.S.A.) conifer forests. Conserv. Biol. 9, 1041-1058. doi: 10.1046/j.1523-1739.1995.9051033.x-i1

IPCC. (2012). Managing the Risks of Extreme Events and Disasters to Advance Climate Change Adaption. Special report of the Intergovernmental Panel on Climate Change. New York, NY: Cambridge University Press.

Kallis, G., Gómez-Baggethun, E., and Zografos, C. (2013). To value or not to value? That is not the question. Ecol. Econ. 94, 97-105. doi: 10.1016/j.ecolecon.2013.07.002

Kaplan, M. (2011). National Outline Plan for Forests and Afforestation: NOP 22 Policy Document. Jerusalem: Maor Wallach Ltd.
Keeler, B. L., Hamel, P., McPhearson, T., Hamann, M. H., Donahue, M. L., Prado, K. A. M., et al. (2019). Social-ecological and technological factors moderate the value of urban nature. Nat. Sustain. 2:29. doi: 10.1038/s41893-018-0202-1

Keeley, J. E. (2001). Fire and Invasives in Mediterranean-Climate Ecosystems of California, eds K. E. M. Galley and T. P. Wilson (Tallahassee, FL: Tall Timbers Research Station). Available online at: http://pubs.er.usgs.gov/publication/ 70006760

Kéfi, S., Rietkerk, M., Alados, C. L., Pueyo, Y., Papanastasis, V. P., Elaich, A., et al. (2007). Investigating Patchiness of Spatially Organized Ecosystems Using Field and Simulated Data. Available online at: https://www.nature.com/ protocolexchange/protocols/300 (accessed February 7, 2019).

Kosoy, N., and Corbera, E. (2010). Payments for ecosystem services as commodity fetishism. Ecol. Econ. 69, 1228-1236. doi: 10.1016/j.ecolecon.2009.11.002

Lampin-Maillet, C., Jappiot, M., Long, M., Bouillon, C., Morge, D., and Ferrier, J.-P. (2010). Mapping wildland-urban interfaces at large scales integrating housing density and vegetation aggregation for fire prevention in the South of France. J. Environ. Manage. 91, 732-741. doi: 10.1016/j.jenvman.2009.10.001

Layke, C. (2009). Measuring Nature's Benefits: A Preliminary Roadmap for Improving Ecosystem Service Indicators. Washington DC: World Resources Institute.

Lee, C., Schlemme, C., Murray, J., and Unsworth, R. (2015). The cost of climate change: ecosystem services and wildland fires. Ecol. Econ. 116, 261-269. doi: 10.1016/j.ecolecon.2015.04.020

Lele, S., Springate-Baginski, O., Lakerveld, R., Deb, D., and Dash, P. (2013). Ecosystem services: origins, contributions, pitfalls, and alternatives. Conserv. Soc. 11:343. doi: 10.4103/0972-4923.125752

Loehle, C. (2004). Applying landscape principles to fire hazard reduction. For. Ecol. Manag. 198, 261-267. doi: 10.1016/j.foreco.2004.04.010

Lyytimäki, J., Petersen, L. K., Normander, B., and Bezák, P. (2008). Nature as a nuisance? Ecosystem services and disservices to urban lifestyle. Environ. Sci. 5, 161-172. doi: 10.1080/15693430802055524

Lyytimäki, J., and Sipilä, M. (2009). Hopping on one leg - the challenge of ecosystem disservices for urban green management. Urban For. Urban Green 8, 309-315. doi: 10.1016/j.ufug.2009.09.003

MacDonald, D., Crabtree, J. R., Wiesinger, G., Dax, T., Stamou, N., Fleury, P., et al. (2000). Agricultural abandonment in mountain areas of Europe: environmental consequences and policy response. J. Environ. Manage. 59, 47-69. doi: 10.1006/jema.1999.0335

Martínez, J., Vega-Garcia, C., and Chuvieco, E. (2009). Human-caused wildfire risk rating for prevention planning in Spain. J. Environ. Manage. 90, 1241-1252. doi: 10.1016/j.jenvman.2008.07.005

McPhearson, T., Pickett, S. T. A., Grimm, N. B., Niemelä, J., Alberti, M., Elmqvist, T., et al. (2016). Advancing urban ecology toward a science of cities. BioScience 66, 198-212. doi: 10.1093/biosci/biw002

Mell, W. E., Manzello, S. L., Maranghides, A., Butry, D., and Rehm, R. G. (2010). The wildland-urban interface fire problem - current approaches and research needs. Int. J. Wildland Fire 19, 238-251. doi: 10.1071/WF07131

Millenium Ecosystem Assessment (2005). Ecosystems and Human Well-Being: Current State and Trends: Findings of the Condition and Trends Working Group of the Millennium Ecosystem Assessment. Washington, DC: Island Press.

Mitchell, J. K. (2003). European River floods in a changing world. Risk Anal. 23, 567-574. doi: 10.1111/1539-6924.00337

Mitchell, S. R., Harmon, M. E., and O'Connell, K. E. B. (2009). Forest fuel reduction alters fire severity and long-term carbon storage in three Pacific Northwest ecosystems. Ecol. Appl. 19, 643-655. doi: 10.1890/08-0501.1

Mitsopoulos, I. D., and Dimitrakopoulos, A. P. (2007). Canopy fuel characteristics and potential crown fire behavior in Aleppo pine (Pinus halepensis Mill.) forests. Ann. For. Sci. 64, 287-299. doi: 10.1051/forest:2007006

Modugno, S., Balzter, H., Cole, B., and Borrelli, P. (2016). Mapping regional patterns of large forest fires in Wildland-Urban Interface areas in Europe. J. Environ. Manage. 172, 112-126. doi: 10.1016/j.jenvman.2016.02.013

Moritz, M. A., Batllori, E., Bradstock, R. A., Gill, A. M., Handmer, J., Hessburg, P. F., et al. (2014). Learning to coexist with wildfire. Nature 515, 58-66. doi: 10.1038/nature 13946

Murray, B. R., Hardstaff, L. K., and Phillips, M. L. (2013). Differences in leaf flammability, leaf traits and flammability-trait relationships between native 
and exotic plant species of dry sclerophyll forest. PLoS ONE 8:e79205. doi: 10.1371/journal.pone.0079205

Naveh, Z. (1973). "The ecology of fire in Israel," in Proceedings of the 13th Annual Tall Timbers Fire Ecology Conference, ed E. V. Komarek (Tallahassee, FL), 131-170.

Naveh, Z. (1975). The evolutionary significance of fire in the Mediterranean region. Vegetatio 29, 199-208. doi: 10.1007/BF02390011

Naveh, Z., and Carmel, Y. (2004). "The evolution of the cultural Mediterranean landscape in Israel as affected by fire, grazing, and human activities," in Evolutionary Theory and Processes: Modern Horizons, ed S. Wasser (Springer, Dordrecht), 337-409 doi: 10.1007/978-94-017-0443-4_18

Ne'eman, G., Goubitz, S., and Nathan, R. (2004). Reproductive traits of Pinus halepensis in the light of fire - a critical review. Plant Ecol. 171, 69-79. doi: 10.1023/B:VEGE.0000029380.04821.99

Ne'eman, G., Perevolotsky, A., and Schiller, G. (1997). The management implications of the mt. Carmel research project. Int. J. Wildland Fire 7, 343-350. doi: $10.1071 /$ wf9970343

Nel, J. L., Maitre, D. C. L., Nel, D. C., Reyers, B., Archibald, S., Wilgen, B. W., et al. (2014). Natural hazards in a changing world: a case for ecosystem-based management. PLoS ONE 9:e95942. doi: 10.1371/journal.pone.0095942

Noss, R. F., Franklin, J. F., Baker, W. L., Schoennagel, T., and Moyle, P. B. (2006). Managing fire-prone forests in the western United States. Front. Ecol. Environ. 4, 481-487. doi: 10.1890/1540-9295(2006)4[481:MFFITW]2.0.CO;2

Orenstein, D. E., Groner, E., Argaman, E., Boeken, B., Preisler, Y., Shachak, M., et al. (2012). An ecosystem services inventory: lessons from the northern Negev long-term social ecological research (LTSER) platform. Geogr. Res. Forum 32, 96-118.

Osem, Y., Ginsberg, P., Tauber, I., Atzmon, N., and Perevolotsky, A. (2008). Sustainable management of mediterranean planted coniferous forests: an Israeli definition. J. For. 106, 38-46. doi: 10.1093/jof/106.1.38

Outeiro, L., Ojea, E., Rodrigues, J. G., Himes-Cornell, A., Belgrano, A., Liu, Y., et al. (2017). The role of non-natural capital in the co-production of marine ecosystem services. Int. J. Biodivers. Sci. Ecosyst. Serv. Manag. 13, 35-50. doi: 10.1080/21513732.2017.1415973

Palomo, I., Felipe-Lucia, M. R., Bennett, E. M., Martín-López, B., and Pascual, U. (2016). "Chapter six - disentangling the pathways and effects of ecosystem service co-production," in Advances in Ecological Research Ecosystem Services: From Biodiversity to Society, Part 2., eds G. Woodward and D. A. Bohan (London; Oxford; San Diego, CA; Cambridge: Academic Press), $245-283$.

Parks, S. A., Holsinger, L. M., Miller, C., and Nelson, C. R. (2015). Wildland fire as a self-regulating mechanism: the role of previous burns and weather in limiting fire progression. Ecol. Appl. 25, 1478-1492. doi: 10.1890/14-1430.1

Pausas, J. G., and Fernández-Muñoz, S. (2012). Fire regime changes in the Western Mediterranean Basin: from fuel-limited to drought-driven fire regime. Clim. Change 110, 215-226. doi: 10.1007/s10584-011-0060-6

Pausas, J. G., and Keeley, J. E. (2019). Wildfires as an ecosystem service. Front. Ecol. Environ. 17, 289-295. doi: 10.1002/fee.2044

Pausas, J. G., Llovet, J., Rodrigo, A., and Vallejo, R. (2008). Are wildfires a disaster in the Mediterranean basin? - A review. Int. J. Wildland Fire 17:713. doi: 10.1071/WF07151

Pereira, M. G., Hayes, J. P., Miller, C., and Orenstein, D. E. (2017). "Fire on the Hills: an environmental history of fires and fire policy in Mediterranean-type ecosystems," in Environmental History in the Making Environmental History. (Cham: Springer), 145-169.

Pereira, P., Mierauskas, P., Ubeda, X., Mataix-Solera, J., and Cerda, A. (2012). Fire in protected areas - the effect of protection and importance of fire management. Environ. Res. Eng. Manag. 59, 52-62. doi: 10.5755/j01.erem.59.1.856

Perevolotsky, A. (2011). Recommendations of the Committee Forest Management and Ecological Restoration of the Carmel. Jerusalem: Multiple.

Perevolotsky, A., and Seligman, N. G. (1998). Role of grazing in mediterranean rangeland ecosystems. Biosci. Oxf. 48, 1007-1017.

Pollet, J., and Omi, P. N. (2002). Effect of thinning and prescribed burning on crown fire severity in ponderosa pine forests. Int. J. Wildland Fire 11, 1-10. doi: 10.1071/wf01045

Radeloff, V. C., Hammer, R. B., Stewart, S. I., Fried, J. S., Holcomb, S. S., and McKeefry, J. F. (2005). The wildland-urban interface in the United States. Ecol. Appl. 15, 799-805. doi: 10.1890/04-1413
Renaud, F. G., Sudmeier-Rieux, K., and Estrella, M. (eds.). (2013). The Role of Ecosystems in Disaster Risk Reduction. Shibuya-ku: United Nations University Press.

Reyers, B., Biggs, R., Cumming, G. S., Elmqvist, T., Hejnowicz, A. P., and Polasky, S. (2013). Getting the measure of ecosystem services: a social-ecological approach. Front. Ecol. Environ. 11, 268-273. doi: 10.1890/120144

Reyers, B., Nel, J. L., O'Farrell, P. J., Sitas, N., and Nel, D. C. (2015). Navigating complexity through knowledge coproduction: mainstreaming ecosystem services into disaster risk reduction. Proc. Natl. Acad. Sci. U S A. 112, 7362-7368. doi: 10.1073/pnas.1414374112

Richardson, D. M., and Wilgen, B. W. V. (2004). Invasive alien plants in South Africa: how well do we understand the ecological impacts? South Afr. J. Sci. 100, 45-52. Available online at: https://hdl.handle.net/10520/EJC96214

Rossiter, N. A., Setterfield, S. A., Douglas, M. M., and Hutley, L. B. (2003). Testing the grass-fire cycle: alien grass invasion in the tropical savannas of northern Australia. Divers. Distrib. 9, 169-176. doi: 10.1046/j.1472-4642.2003.00020.x

Ruiz-Mirazo, J., and Robles, A. B. (2012). Impact of targeted sheep grazing on herbage and holm oak saplings in a silvopastoral wildfire prevention system in south-eastern Spain. Agrofor. Syst. 86, 477-491. doi: $10.1007 / \mathrm{s} 10457-012-9510-\mathrm{z}$

Safriel, U. N. (1997). The Carmel fire and its conservation repercussions. Int. J. Wildland Fire 7, 277-284. doi: 10.1071/wf9970277

Schmerbeck, J., Kohli, A., and Seeland, K. (2015). Ecosystem services and forest fires in India - context and policy implications from a case study in Andhra Pradesh. For. Policy Econ. 50, 337-346. doi: 10.1016/j.forpol.2014.09.012

Shang, B. Z., He, H. S., Crow, T. R., and Shifley, S. R. (2004). Fuel load reductions and fire risk in central hardwood forests of the united states: a spatial simulation study. Ecol. Model. 180, 89-102. doi: 10.1016/j.ecolmodel.2004.01.020

Sil, Â., Fernandes, P. M., Rodrigues, A. P., Alonso, J. M., Honrado, J. P., Perera, A., et al. (2019). Farmland abandonment decreases the fire regulation capacity and the fire protection ecosystem service in mountain landscapes. Ecosyst. Serv. 36:100908. doi: 10.1016/j.ecoser.2019.100908

Spangenberg, J. H., von Haaren, C., and Settele, J. (2014). The ecosystem service cascade: further developing the metaphor. Integrating societal processes to accommodate social processes and planning, and the case of bioenergy. Ecol. Econ. 104, 22-32. doi: 10.1016/j.ecolecon.2014.04.025

Spies, T. A., Hemstrom, M. A., Youngblood, A., and Hummel, S. (2006). Conserving old-growth forest diversity in disturbance-prone landscapes. Conserv. Biol. 20, 351-362. doi: 10.1111/j.1523-1739.2006.00389.x

Stemple, J. (1998). A brief review of afforestation efforts in Israel. Rangelands 20, $15-18$.

Stephens, S. L., Burrows, N., Buyantuyev, A., Gray, R. W., Keane, R. E., Kubian, R., et al. (2014). Temperate and boreal forest mega-fires: characteristics and challenges. Front. Ecol. Environ. 12, 115-122. doi: 10.1890/120332

Tal, A. (2013). All the Trees of the Forest: Israel's Woodlands From the Bible to the Present. New Haven, CT: Yale University Press.

Tal, A. (2016). Israel's New Bible of Forestry and the Pursuit of Sustainable Dryland Afforestation. Geogr. Res. Forum 32, 81-95.

Taylor, C. A. Jr. (2006). "Targeted grazing to manage fire risk," in Targeted Grazing: A Natural Approach to Vegetation Management and Landscape Enhancement, ed K. Launchbaugh, 107-112. Available online at: https://www.webpages. uidaho.edu/rx-grazing/Handbook.htm

TEEB (2012). "The economics of ecosystems and biodiversity: ecological and economic foundations," ed. P. Kumar (Routledge). Available online at: http://www.teebweb.org/our-publications/teeb-study-reports/ecological-andeconomic-foundations/ (accessed October 5, 2014).

Thom, D., and Seidl, R. (2016). Natural disturbance impacts on ecosystem services and biodiversity in temperate and boreal forests: disturbance impacts on biodiversity and services. Biol. Rev. 91, 760-781. doi: 10.1111/brv.12193

Turco, M., Bedia, J., Liberto, F. D., Fiorucci, P., Hardenberg, J., von, Koutsias, N., et al. (2016). Decreasing Fires in Mediterranean Europe. PLoS ONE 11:e0150663. doi: 10.1371/journal.pone.0150663

Valkó, O., Török, P., Deák, B., and Tóthmérész, B. (2014). Review: prospects and limitations of prescribed burning as a management tool in European grasslands. Basic Appl. Ecol. 15, 26-33. doi: 10.1016/j.baae.20 13.11.002

Vaz, A. S., Kueffer, C., Kull, C. A., Richardson, D. M., Vicente, J. R., Kühn, I., et al. (2017). Integrating ecosystem services and disservices: insights 
from plant invasions. Ecosyst. Serv. 23, 94-107. doi: 10.1016/j.ecoser.2016. 11.017

Vilà-Cabrera, A., Coll, L., Martínez-Vilalta, J., and Retana, J. (2018). Forest management for adaptation to climate change in the Mediterranean basin: a synthesis of evidence. For. Ecol. Manag. 407, 16-22. doi: 10.1016/j.foreco.2017.10.021

Wagner, S. A., and Fraterrigo, J. M. (2015). Positive feedbacks between fire and non-native grass invasion in temperate deciduous forests. For. Ecol. Manag. 354, 170-176. doi: 10.1016/j.foreco.2015.06.024

Wallace, K. (2008). Ecosystem services: multiple classifications or confusion? Biol. Conserv. 141, 353-354. doi: 10.1016/j.biocon.2007.12.014

Wallace, K. J. (2007). Classification of ecosystem services: problems and solutions. Biol. Conserv. 139, 235-246. doi: 10.1016/j.biocon.2007.07.015

WERT (2018). Camp Fire. Watershed Emergency Response Team Final Report. California Watershed Emergency Response Team (WERT).

Westerling, A. L., Hidalgo, H. G., Cayan, D. R., and Swetnam, T. W. (2006). Warming and Earlier Spring Increase Western U.S. Forest Wildf. Activity. Sci. 313, 940-943. doi: $10.1126 /$ science. 1128834
Wittenberg, L., and Inbar, M. (2009). the role of fire disturbance on runoff and erosion processes - a long-term approach, Mt. Carmel Case Study. Israel. Geogr. Res. 47, 46-56. doi: 10.1111/j.1745-5871.2008. 00554.x

Wittenberg, L., and Malkinson, D. (2009). Spatio-temporal perspectives of forest fires regimes in a maturing Mediterranean mixed pine landscape. Eur. J. For. Res. 128:297. doi: 10.1007/s10342-009-0265-7

Conflict of Interest Statement: The authors declare that the research was conducted in the absence of any commercial or financial relationships that could be construed as a potential conflict of interest.

Copyright (๑) 2019 Depietri and Orenstein. This is an open-access article distributed under the terms of the Creative Commons Attribution License (CC BY). The use, distribution or reproduction in other forums is permitted, provided the original author(s) and the copyright owner(s) are credited and that the original publication in this journal is cited, in accordance with accepted academic practice. No use, distribution or reproduction is permitted which does not comply with these terms. 